DOI: $10.14720 /$ aas.2016.107.2.18

Agrovoc descriptors: wines, white wines, antioxidants, phenolic compounds, phenols, winemaking, lees, wine yeast

Agris category code: Q01, Q02, Q04

\title{
Comparison of total polyphenols content and antioxidant potential of wines from 'Welschriesling' and 'Sauvignon Blanc' varieties during ageing on fine lees
}

\author{
Jasna LUŽAR ${ }^{1}$, Tjaša $J_{U G}^{2}$, Polona JAMNIK $^{3}$, Tatjana KOŠMERL ${ }^{3}$
}

Received July 29, 2016; accepted September 30, 2016.

Delo je prispelo 29. julija 2016, sprejeto 30. septembra 2016.

\begin{abstract}
Phenolic compounds are key components of wine, since they contribute to wine characteristics such as colour, astringency and bitterness. They also act like antioxidants, with mechanisms involving free-radical scavenging that could prevent cardiovascular diseases and cancer. The aim of the present work was to compare the obtained results of total polyphenols content and antioxidant potential (AOP) of several white wines (welschriesling and sauvignon blanc) during ageing on fine lees. The total polyphenols content decreased in average for $16.1 \%$ in welschriesling wines and for $18.7 \%$ in sauvignon blanc wines in the period of three months of wine ageing on lees. In the same period AOP of wines decreased in average for $16.0 \%$ in welschriesling wines and for $8.0 \%$ in sauvignon blanc wines. Expectedly, the samples with added oak chips in grape must had higher antioxidant potential than others.
\end{abstract}

Key words: white wines, antioxidant potential, phenolic compounds, DPPH, yeast lees

\section{IZVLEČEK}

\author{
PRIMERJAVA VSEBNOSTI CELOKUPNIH FENOLOV \\ IN ANTIOKSIDATIVNEGA POTENCIALA VIN IZ \\ SORT 'Welschriesling' IN 'Sauvignon Blanc' MED \\ STARANJEM NA FINIH DROŽEH
}

Fenolne spojine so ključne sestavine vina, ki prispevajo $\mathrm{k}$ značilnostim vina, kot so barva, trpkost in grenkoba. Delujejo kot antioksidanti z mehanizmi, ki vključujejo lovljenje prostih radikalov, kar lahko prepreči kardiovaskularne bolezni in raka Namen dela je bil primerjati dobljene rezultate vsebnosti skupnih fenolov in antioksidativni potencial (AOP) belih sortnih vin laški rizling in sauvignon med zorenjem vina na finih drožeh. Trije meseci spremljanja so pokazali, da se je vsebnost skupnih fenolov zmanjšala v povprečju za $16,1 \% \mathrm{v}$ vinih sorte laški rizling in za $18,7 \% \mathrm{v}$ vinih sorte sauvignon. Vrednost AOP se je $\mathrm{v}$ tem času prav tako zmanjšala $\mathrm{v}$ povprečju za $16,0 \%$ pri vinih sorte laški rizling in za $8,0 \%$ pri vinih sorte sauvignon. Pričakovano so imeli vzorci $z$ dodatkom trsk iz hrastovega lesa v mošt večji antioksidativni potencial kot ostali.

Ključne besede: bela vina, antioksidativni potencial, fenolne spojine, DPPH, droži

\section{INTRODUCTION}

Phenolic compounds are key components of wine that not only contribute to the organoleptic characteristics of wine but they also are the main cause of colour changes in wine. The light yellow colour as well as the brown colour in white wines is undesirable due to the higher content of phenolics and its oxidation. Nevertheless, phenolic compounds also act as antioxidants, with mechanisms involving free-radical scavenging that

\footnotetext{
University of Ljubljana, Biotechnical Faculty, Jamnikarjeva 11, SI-1000 Ljubljana, M.Sc., email: jluzar2@gmail.com

2 Chamber of Agriculture and Forestry of Slovenia, Institute for Agriculture and Forestry, Pri hrastu 18,5000 Nova Gorica, Ph.D

3 University of Ljubljana, Biotechnical Faculty, Jamnikarjeva 11, SI-1000 Ljubljana, Ph.D., email: tatjana.kosmerl@bf.uni-lj.si, polona.jamnik@bf.uni-lj.si
} 
we are examining (Peréz-Serradilla and Luque de Castro, 2008).

White wines are characterised by lower concentrations of total polyphenols (typically 200$500 \mathrm{mg} \mathrm{l}^{-1}$ ) than red wines because of a lack of redcoloured anthocyanins; white wines are additionally characterized by the predominance of hydroxycinnamic acids (Kilmartin, 2010). Phenolic compounds have received much attention in the prevention of human cardiovascular disorders and cancer due to their antioxidant properties (Paixão et al., 2007). Cells of aerobic organisms are constantly exposed to the effects of reactive oxygen species (ROS) - free radicals. Phenolic compounds have a functional role as they behave as antioxidants against the free radicals. We could say that they increase the antioxidant capacity in the human body after (especially red) wine consumption (Serafini et al., 1998).

We were monitoring the total polyphenols content and antioxidant potential of wine during ageing on fine lees. Yeast cells have been shown to exert a protective effect toward polyphenol oxidation during ageing on lees (Salmon et al., 2002). They have a role as a competing substrate for oxygen in wine. During alcoholic fermentation, yeast cells require oxygen for their metabolic activity and the reactive oxygen species that are produced can potentially oxidise wine polyphenols. At the end of fermentation, phenolic compounds take part in oxygen consumption. After completion of alcoholic fermentation, yeast lees can consume oxygen for up to 3 years in contact with ageing wine. The consumption of oxygen by yeast lees has been ascribed to a mild oxidation of the membrane lipids of the yeast lees that leads to lipid peroxides and further products that may add to the wine flavour (Kilmartin, 2010).

The aim of the present work was to compare the obtained results of total polyphenols content and AOP of several white wines (from 'Welschriesling' and 'Sauvignon Blanc' varieties) during wine ageing on fine lees.

\section{MATERIALS AND METHODS}

\subsection{Samples}

We collected 35 samples of Slovenian wines (18 samples of welschriesling and 17 samples of sauvignon blanc wines) and then examined the content of total polyphenols and AOP of these young wines. Investigated samples were taken one week after alcoholic fermentation was completed (at time $\mathrm{t}=0$ ). Wine ageing was performed in the cooling room of Biotechnical Faculty at temperature $4{ }^{\circ} \mathrm{C}$. No sulphite was added to welschriesling and sauvignon blanc wines. We were monitoring content of total polyphenols and AOP of wine at different times - at time $t_{1}=0$, $\mathrm{t}_{2}=14$ days, $\mathrm{t}_{3}=28$ days, $\mathrm{t}_{4}=48$ days and $\mathrm{t}_{5}=76$ days, during wine ageing on fine lees.

\subsection{Folin-Ciocalteu assay}

Total polyphenols were determined by FolinCiocalteu (FC) spectrofotometric method (Singleton and Rossi, 1965).

Undiluted samples of white wine and gallic acid (used as a standard) were incubated in sodium carbonate solution $\left(20 \%, \mathrm{w} \mathrm{v}^{-1}\right)$ and $\mathrm{FC}$ reagent for 2 hours at room temperature. The absorbance was measured at wavelength $765 \mathrm{~nm}$. Measured absorbance is proportional to mass concentration of phenolic compounds and it is expressed as gallic acid equivalents ( $\mathrm{mg}$ of gallic acid per litre of wine). The determination was performed in duplicate and the results are expressed as the mean value.

\subsection{Determination of antioxidant potential (AOP) of wine with the 1-diphenyl-2- picrylhydrazyl radical (DPPH') scavenging method}

Antioxidant potential of wine was determined by $\mathrm{DPPH}^{\circ}$ radical scavenging method (BrandWilliams et al., 1996). DPPH solution in $99 \%$ methanol was added to $50 \mu$ l diluted sample $(\mathrm{R}=2)$. After $30 \mathrm{~min}$, the absorbance was measured at $517 \mathrm{~nm}$. For each sample there was a blank (methanol) and reference (DPPH'solution). When antioxidant reacts with the DPPH radical and radical becomes a stable molecule, a decrease in 
absorbance occurs. DPPH ${ }^{\bullet}$ scavenging ability is expressed as concentration of $\mathrm{DPPH}^{*}$ in $\mathrm{mmol}^{-1}$.
The determination was performed in triplicates and the results are expressed as the mean value.

\section{RESULTS AND DISCUSSION}

\subsection{Antioxidant potential (AOP) of wines}

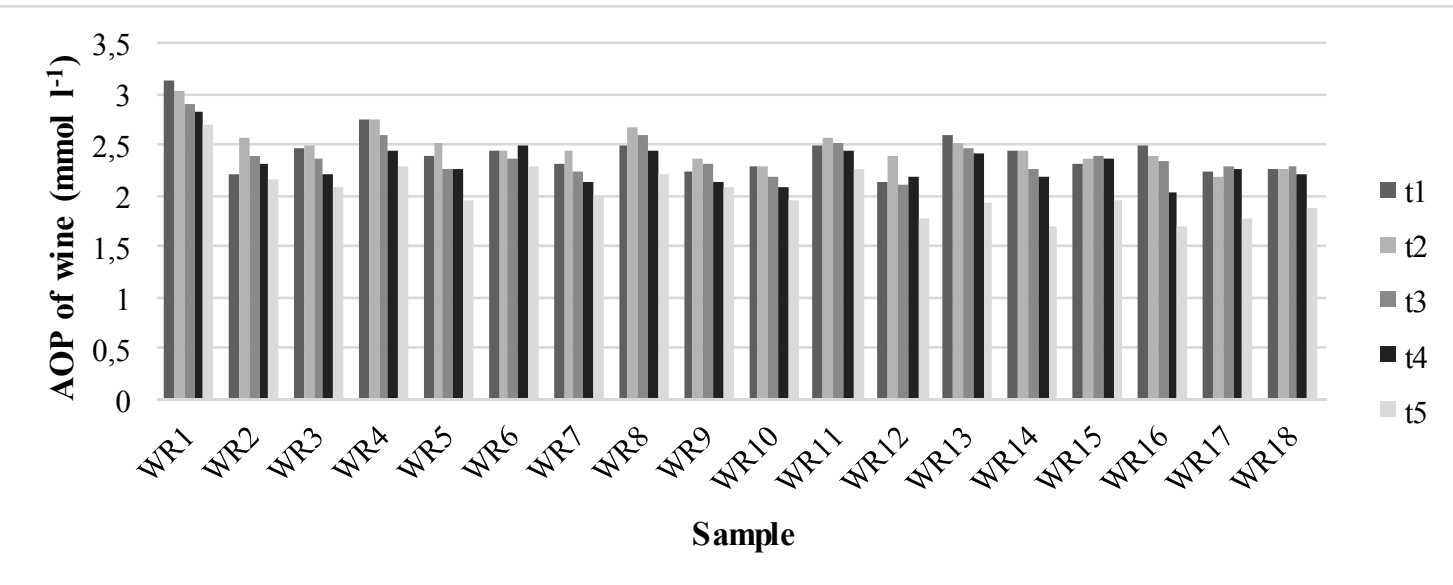

Figure 1: AOP of welschriesling wines at different sampling times $\left(t_{1}=0, t_{2}=14\right.$ days, $t_{3}=28$ days, $t_{4}=48$ days and $\mathrm{t}_{5}=76$ days) after completion of alcoholic fermentation

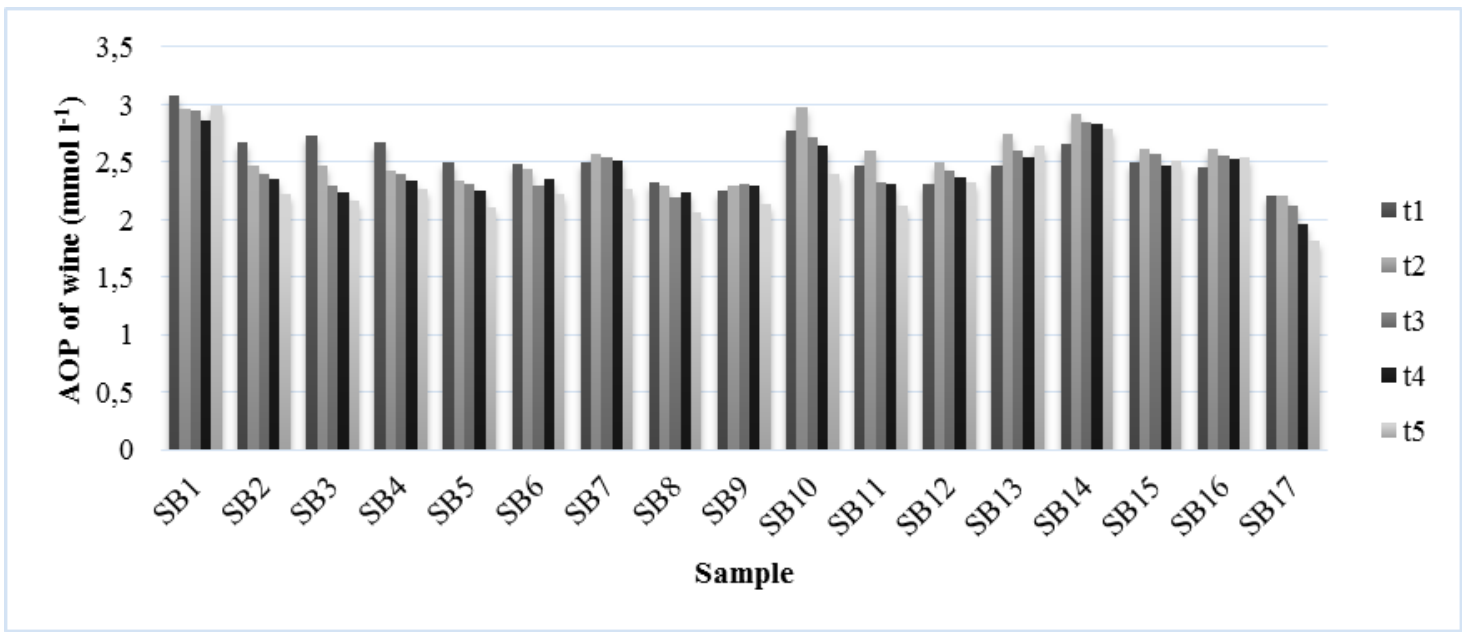

Figure 2: AOP of sauvignon blanc wines at different sampling times $\left(t_{1}=0, t_{2}=14\right.$ days, $t_{3}=28$ days, $t_{4}=48$ days and $t_{5}=76$ days) after completion of alcoholic fermentation

The results of the AOP of welschriesling and sauvignon blanc wines are presented in Figure 1 and Figure 2, respectively. Both Figures show the gradually decrease of antioxidant potential of welschriesling and sauvignon blanc wines as a function of wine ageing on fine lees. We noticed the increase of AOP in some of the wine samples that decreased at the next sampling. The most obvious was this phenomenon of the AOP increasing at the second time of sampling in welschriesling wines WR2, WR8, WR11, and in sauvignon blanc wines SB7, SB10 and SB12SB16. The increase of AOP of wine could be caused by the antioxidant defence system of yeast the increase in antioxidant content and increase in the levels of antioxidant enzymes including superoxide dismutase and glutathione reductase on yeast entering into the stationary phase, may 
constitute adaptive response to the enhanced oxidative stress (Jakubowski et al., 1999).

Table 1: Content of reducing sugars (RS), content of total polyphenols (PFT), FC index and antioxidant potential (AOP) after 76 days of wine ageing on fine lees.

\begin{tabular}{|c|c|c|c|c|}
\hline Sample & $\begin{array}{l}\mathrm{RS} \\
\left(\mathrm{g} \mathrm{l}^{-1}\right)\end{array}$ & PFT $\left(\mathrm{mg} \mathrm{GAE}^{-1}{ }^{-1}\right)$ & FC index (/) & $\mathrm{AOP}\left(\mathrm{mmol} \mathrm{l}^{-1}\right)$ \\
\hline \multicolumn{5}{|c|}{ welschriesling wines } \\
\hline WR1 (control) & 117.2 & 444.6 & 36 & 2.70 \\
\hline WR2 & 3.1 & 327.6 & 6 & 2.17 \\
\hline WR3 & 1.1 & 322.1 & 6 & 2.08 \\
\hline WR4 & 1.5 & 331.1 & 10 & 2.28 \\
\hline WR5 & 3.6 & 299.5 & 9 & 1.96 \\
\hline WR6 (AM-HT $\left.{ }^{1}\right)$ & 1.9 & 353.1 & 9 & 2.28 \\
\hline WR7 (AM-HT $\left.{ }^{1}\right)$ & 1.4 & 331.1 & 11 & 2.01 \\
\hline WR8 (AM-HT $\left.{ }^{1}\right)$ & 1.4 & 325.8 & 10 & 2.22 \\
\hline WR9 & 1.7 & 324.1 & 7 & 2.07 \\
\hline WR10 & 1.2 & 305.4 & 8 & 1.95 \\
\hline WR11 & 7.7 & 334.1 & 7 & 2.27 \\
\hline WR12 & 3.4 & 297.6 & 7 & 1.76 \\
\hline WR13 & 2.4 & 320.1 & 10 & 1.93 \\
\hline WR14 & 31.4 & 328.6 & 3 & 1.70 \\
\hline WR15 & 1.9 & 328.6 & 10 & 1.95 \\
\hline WR16 & 1.5 & 297.1 & 10 & 1.70 \\
\hline WR17 & 1.4 & 309.0 & 11 & 1.77 \\
\hline WR18 & 1.7 & 322.1 & 10 & 1.87 \\
\hline \multicolumn{5}{|c|}{ sauvignon blanc wines } \\
\hline SB1 (control) & 121.7 & 451.1 & 38 & 2.99 \\
\hline $\mathrm{SB} 2$ & 2.3 & 320.6 & 7 & 2.22 \\
\hline SB3 & 1.3 & 310.1 & 6 & 2.16 \\
\hline SB4 & 2.1 & 315.6 & 9 & 2.27 \\
\hline SB5 & 3.4 & 298.6 & 9 & 2.11 \\
\hline SB6 & 5.0 & 322.2 & 9 & 2.23 \\
\hline SB7 (AM-MT $\left.{ }^{2}\right)$ & 5.2 & 328.6 & 9 & 2.26 \\
\hline SB8 & 1.0 & 284.1 & 4 & 2.06 \\
\hline SB9 & 1.2 & 252.6 & 6 & 2.14 \\
\hline SB10 & 1.3 & 340.6 & 8 & 2.39 \\
\hline SB11 & 1.3 & 311.7 & 7 & 2.12 \\
\hline $\begin{array}{r}\mathrm{SB12} \\
\left(\mathrm{AM}-\mathrm{MT}^{2}\right)\end{array}$ & 1.1 & 294.9 & 4 & 2.33 \\
\hline $\begin{array}{r}\text { SB13 } \\
\left(\text { FR-MT }^{3}\right) \\
\end{array}$ & 1.2 & 356.6 & 10 & 2.65 \\
\hline $\begin{array}{r}\text { SB14 } \\
\left(\text { FR-MT }^{3}\right)\end{array}$ & 1.7 & 371.6 & 9 & 2.79 \\
\hline SB15 $\left(A M-M^{2}\right)$ & 1.5 & 342.6 & 9 & 2.51 \\
\hline SB16 $\left(A M-M^{2}\right)$ & 1.7 & 342.6 & 9 & 2.54 \\
\hline SB17 & 9.1 & 233.1 & 7 & 1.81 \\
\hline
\end{tabular}

${ }^{1}$ Addition of American oak chips (highly toasted), ${ }^{2}$ Addition of American oak chips (medium toast), ${ }^{3}$ Addition of French oak chips (medium toast)

The highest antioxidant potential was measured in a control sample SB1, where spontaneous fermentation was performed, and sample SB14 with addition of French oak chips (medium toast).
As observed from Table 1, the control samples have the highest amount of reducing sugars $\left(\gamma_{\mathrm{RS}(\mathrm{SB} 1)}=121.7 \mathrm{~g} \mathrm{l}^{-1}\right.$ and $\gamma_{\mathrm{RS}(\mathrm{WR} 1)}=117.2 \mathrm{~g} \mathrm{l}^{-1}$; while the average amount of reducing sugars in 
other samples is $\gamma_{\mathrm{RS}}=3.3 \mathrm{~g}^{-1}$ ) and they interfere with free radical DPPH. Because of that it shows greater antioxidant potential than it should.

The lowest antioxidant potential had sample WR16 with addition of commercial yeast strain EC-1118 $\left(40 \mathrm{~g} \mathrm{hl}^{-1}\right)$ and nutrient Naturferm $\left(40 \mathrm{~g} \mathrm{~h}^{-1}\right)$.

On Figure 1 and Figure 2 we can see that wines with added oak chips (samples WR6, WR7, WR8, SB7, SB10, SB12, SB13, SB14, SB15 and SB16) express stronger ability to scavenge $\mathrm{DPPH}^{\circ}$ radical than other samples. AOP of samples SB12-SB16 was even higher at sampling time $t_{5}$ than at sampling $t_{0}$. This could be due to extracted polyphenols from oak chips to wine and therefore increasing AOP of investigated samples.

\subsection{Content of total polyphenols}

As observed from Figure 3 and Figure 4, content of total polyphenols is constantly decreasing during wine ageing on fine lees.

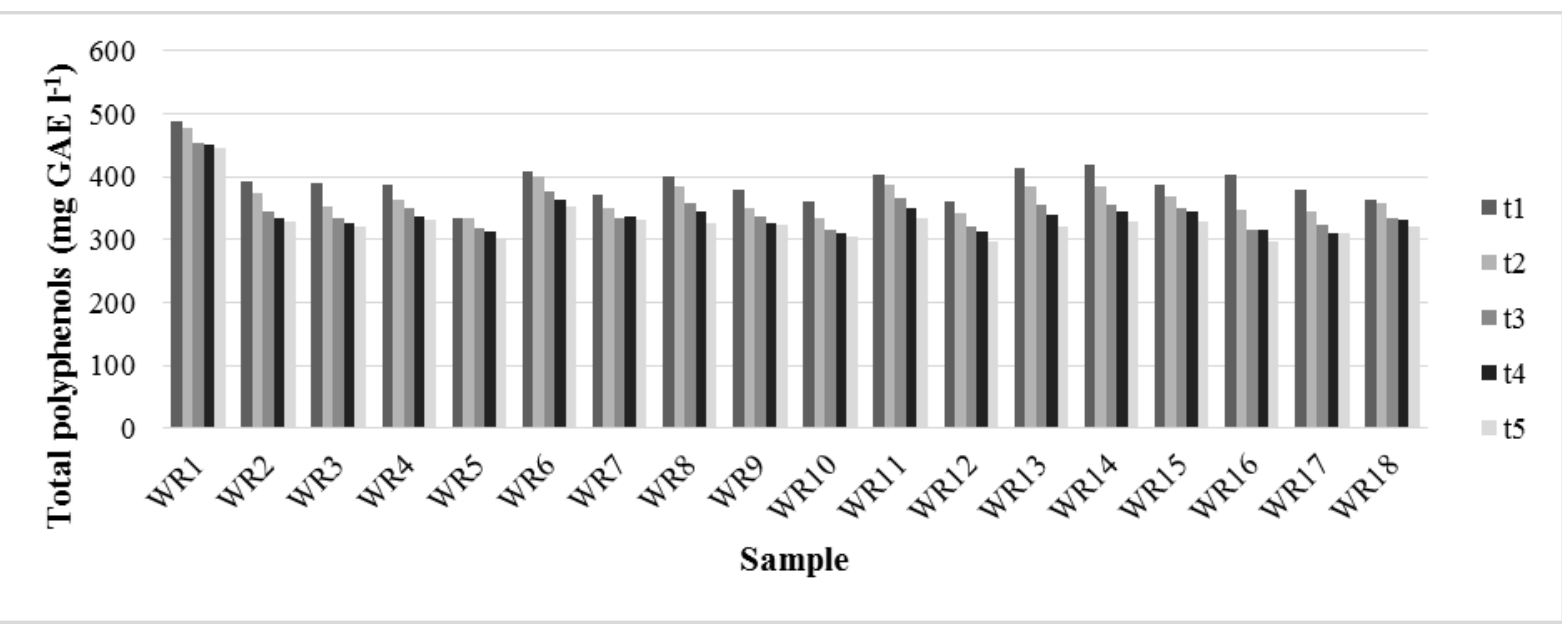

Figure 3: Content of total polyphenols in welschriesling wines at different sampling times $\left(t_{1}=0, t_{2}=14\right.$ days, $t_{3}=$ 28 days, $t_{4}=48$ days and $t_{5}=76$ days) after completion of alcoholic fermentation

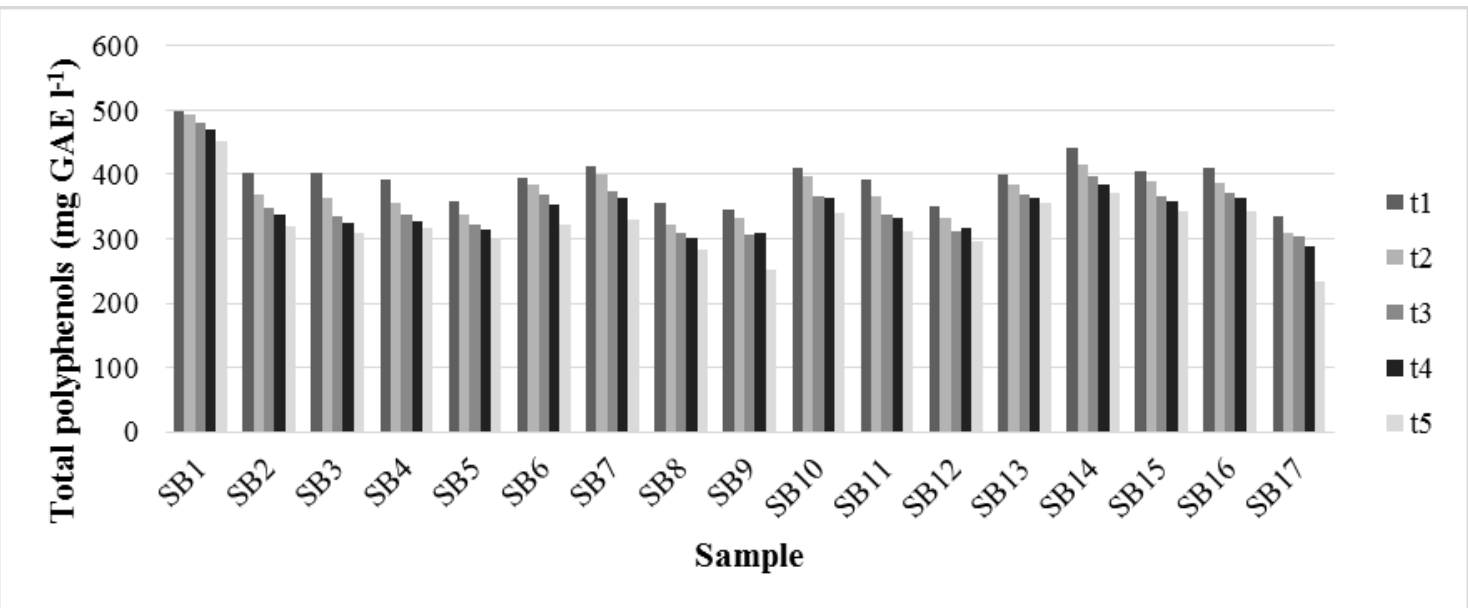

Figure 4: Content of total polyphenols in sauvignon blanc wines at different sampling times $\left(\mathrm{t}_{1}=0, \mathrm{t}_{2}=14\right.$ days, $\mathrm{t}_{3}=$ 28 days, $t_{4}=48$ days and $t_{5}=76$ days) after completion of alcoholic fermentation

The highest content of total polyphenols was determined in samples WR1 and SB1, produced by spontaneous fermentation.
Table 1 lists concentrations of total polyphenols and reducing sugars in both welschriesling and sauvignon blanc wines at sampling time $t_{5}=76$ days. It shows that samples with higher amount of 
reducing sugars have considerably higher content of total polyphenols. The disadvantage of using Folin-Ciocalteu method for determination of total polyphenols is that the mentioned reagent reacts nonspecifically with all phenolic hydroxyl groups $(-\mathrm{OH})$, including aromatic amino acids, ascorbic acid, reducing sugars and organic acids
(Abramovič, 2011). We could clean up samples by a solid phase extraction (SPE) to remove other reducing compounds and to get more accurate results. Therefore our results indicate higher content of total polyphenols and the correction is needed.

Table 2: Correction of total polyphenol content $\left(\mathrm{mg} \mathrm{GAE} \mathrm{l}^{-1}\right)$ with $\mathrm{FC}$ reagent regarding the amount of reducing sugars $\left(\mathrm{g} \mathrm{l}^{-1}\right)$ (Košmerl and Kač, 2010)

\begin{tabular}{|c|l|}
\hline $\begin{array}{c}\text { Reducing sugars } \\
\left(\mathrm{g} \mathrm{l}^{-1}\right)\end{array}$ & $\begin{array}{c}\text { Division factor of total } \\
\text { polyphenols } \\
\text { concentration }\end{array}$ \\
\hline $0-10$ & $/$ \\
\hline $10-25$ & 1.03 \\
\hline $25-100$ & 1.06 \\
\hline $100-200$ & 1.10 \\
\hline
\end{tabular}

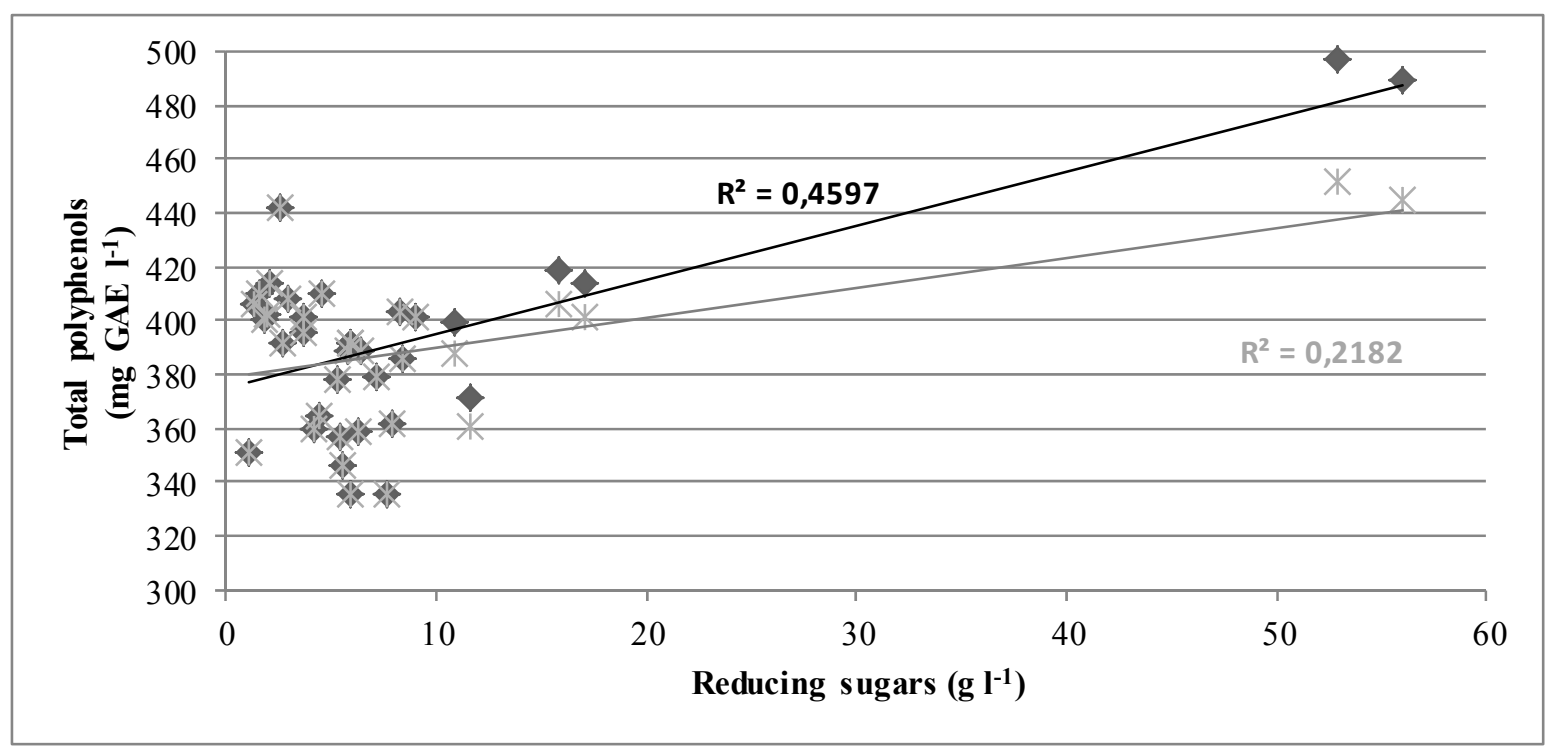

Figure 5: Relation between total polyphenols and reducing sugars with $\left(_{*}\right)$ and without correction $(\bullet)$

The correlation between reducing sugars and total polyphenols (PFT) was even worse after PFTcorrection $\left(\mathrm{R}^{2}=0.2182\right)$ in comparison to noncorrection $\left(\mathrm{R}^{2}=0.4597\right)$ for our investigated samples.

Expectedly, addition of oak chips in grape must of 'Welschriesling' and 'Sauvignon Blanc' varieties (samples WR6, WR7, WR8, SB7, SB10, SB12-16) resulted in much higher content of total polyphenols. We can assume that polyphenols were extracted from oak chips into wine during wine ageing on fine lees and therefore have increased content of total polyphenols.

\subsection{Correlation between total polyphenols and AOP of wines}

Figure 6 and Figure 7 presents the correlation between total polyphenols content and AOP of welschriesling and sauvignon blanc wines. It shows a strong positive dependence of AOP on the content of total polyphenols in all wines of both varieties.

The linear correlation between AOP of wine and total polyphenols concentration was better for sauvignon blanc wines than for welschriesling wines. From these obtained results we can 
conclude that the correlation between AOP and total polyphenols is particularly varietal characteristic as also demonstrated Košmerl and Cigić (2008). Phenolic composition of individual variety has different influence on correlations of total polyphenols with AOP; polyphenols with higher numbers of hydroxyl groups and those having hydroxyl groups in ortho positions in the aromatic rings usually have higher antioxidant potential (Košmerl and Cigić, 2008).

It can be also summarized that the correlation between AOP of wine and total polyphenols concentration has increased during wine ageing on lees.

Table 3: Coefficient of determination $\left(\mathrm{R}^{2}\right)$ for welschriesling wines at different sampling times

\begin{tabular}{|l|l|}
\hline Sampling & Coefficient of determination $\left(R^{2}\right)$ \\
\hline$t_{1}$ & 0.6538 \\
\hline$t_{2}$ & 0.5850 \\
\hline$t_{3}$ & 0.7224 \\
\hline$t_{4}$ & 0.7398 \\
\hline$t_{5}$ & 0.6530 \\
\hline
\end{tabular}

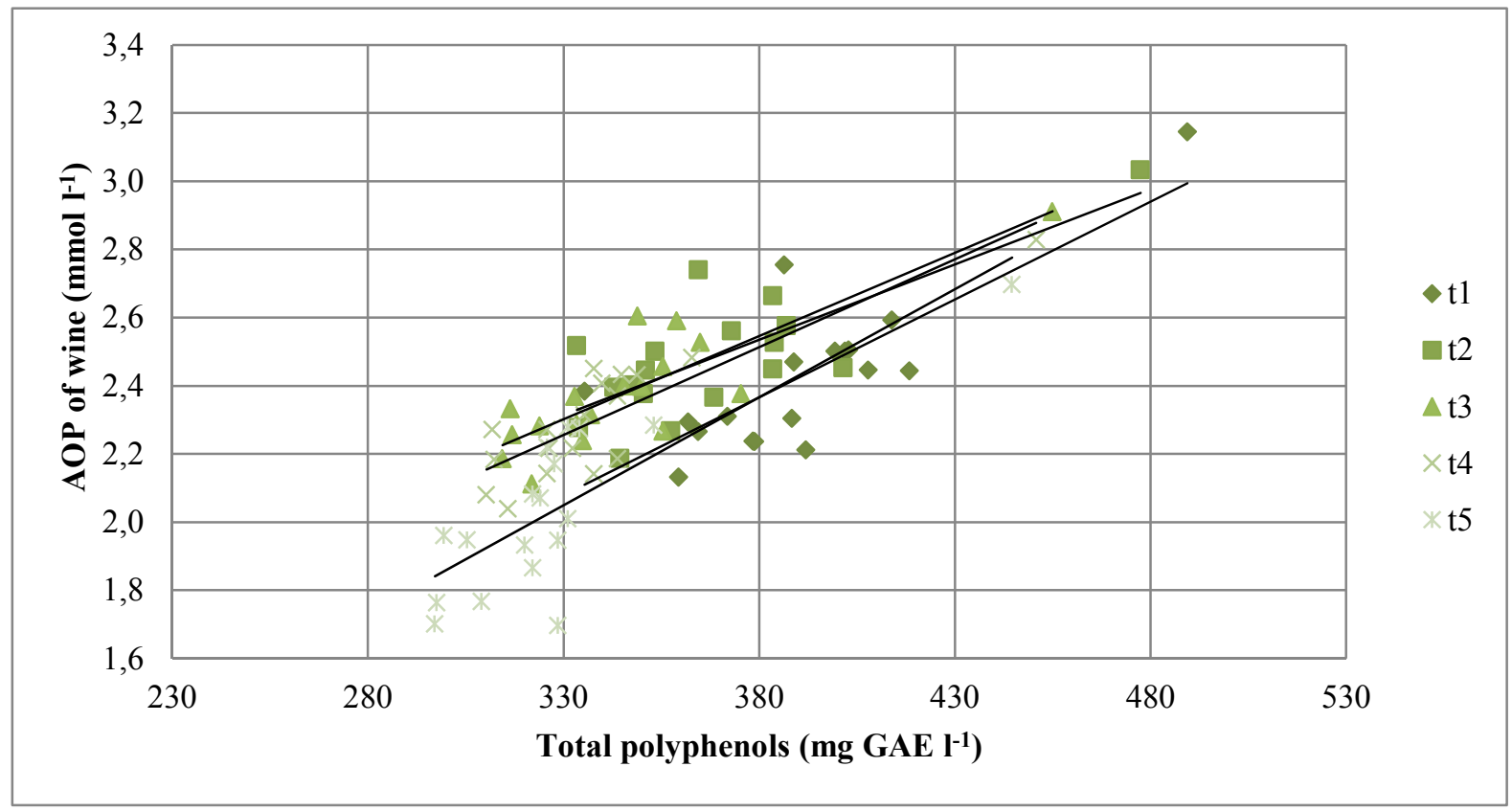

Figure 6: Correlation between total polyphenols and AOP of welschriesling wines at different sampling times $\left(\mathrm{t}_{1}=0\right.$, $\mathrm{t}_{2}=14$ days, $\mathrm{t}_{3}=28$ days, $\mathrm{t}_{4}=48$ days and $\mathrm{t}_{5}=76$ days) after completion of alcoholic fermentation 
Table 4: Coefficient of determination $\left(\mathrm{R}^{2}\right)$ for sauvignon blanc wines at different sampling times

\begin{tabular}{|l|l|}
\hline Sampling & Coefficient of determination $\left(\mathrm{R}^{2}\right)$ \\
\hline $\mathrm{t}_{1}$ & 0.7434 \\
\hline $\mathrm{t}_{2}$ & 0.7141 \\
\hline $\mathrm{t}_{3}$ & 0.7619 \\
\hline $\mathrm{t}_{4}$ & 0.7868 \\
\hline$t_{5}$ & 0.8467 \\
\hline
\end{tabular}

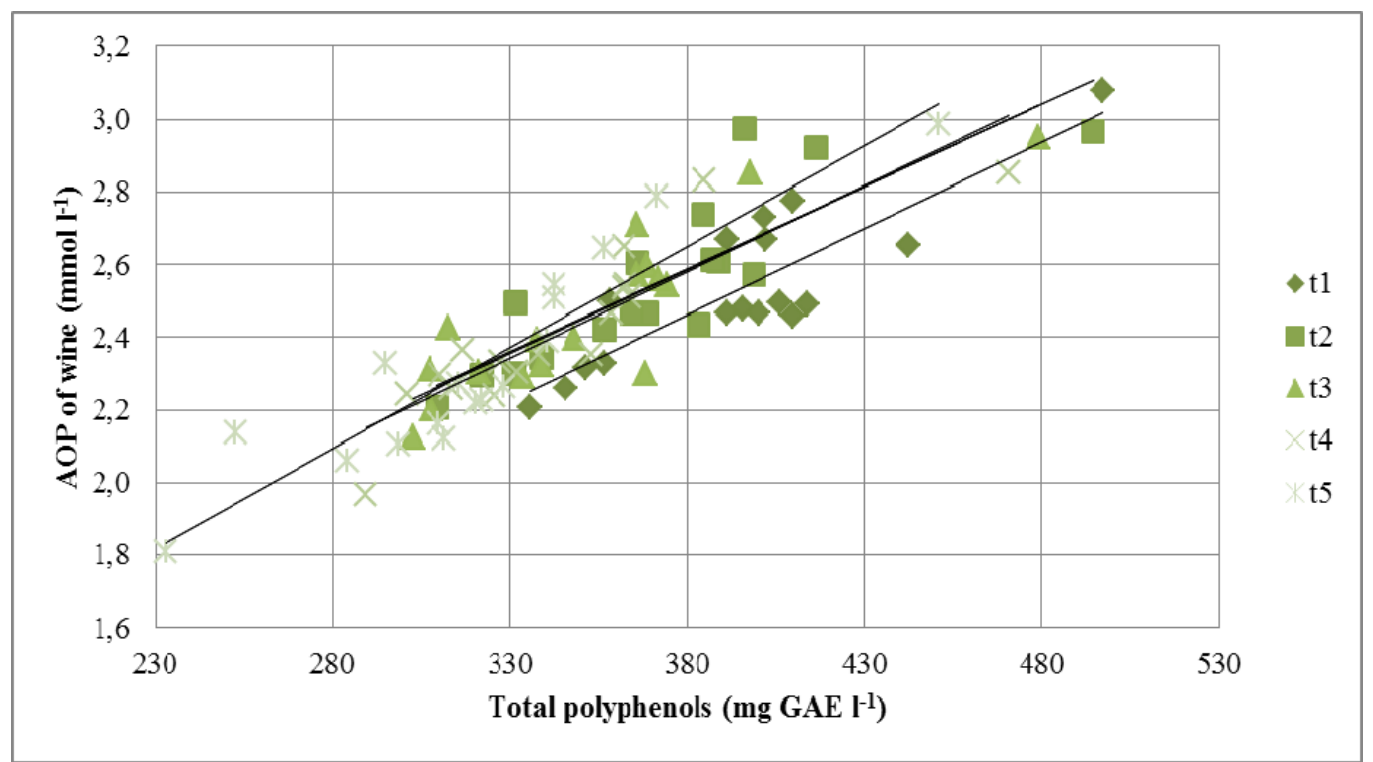

Figure 7: Correlation between total polyphenols and AOP of sauvignon blanc wines at different sampling times $\left(\mathrm{t}_{1}=0, \mathrm{t}_{2}=14\right.$ days, $\mathrm{t}_{3}=28$ days, $\mathrm{t}_{4}=48$ days and $\mathrm{t}_{5}=76$ days $)$ after completion of alcoholic fermentation

\subsection{Correlation between FC index and total polyphenols}

In Table 1 are given informative values for FC index. In the first part we examined correlation between FC index and total polyphenols content and in the second part correlation between reducing sugars and $\mathrm{FC}$ index.
As shown in Figure 8, correlation between FC index and total polyphenols content was very weak in the case of sauvignon blanc wines and higher for welschriesling wines. 


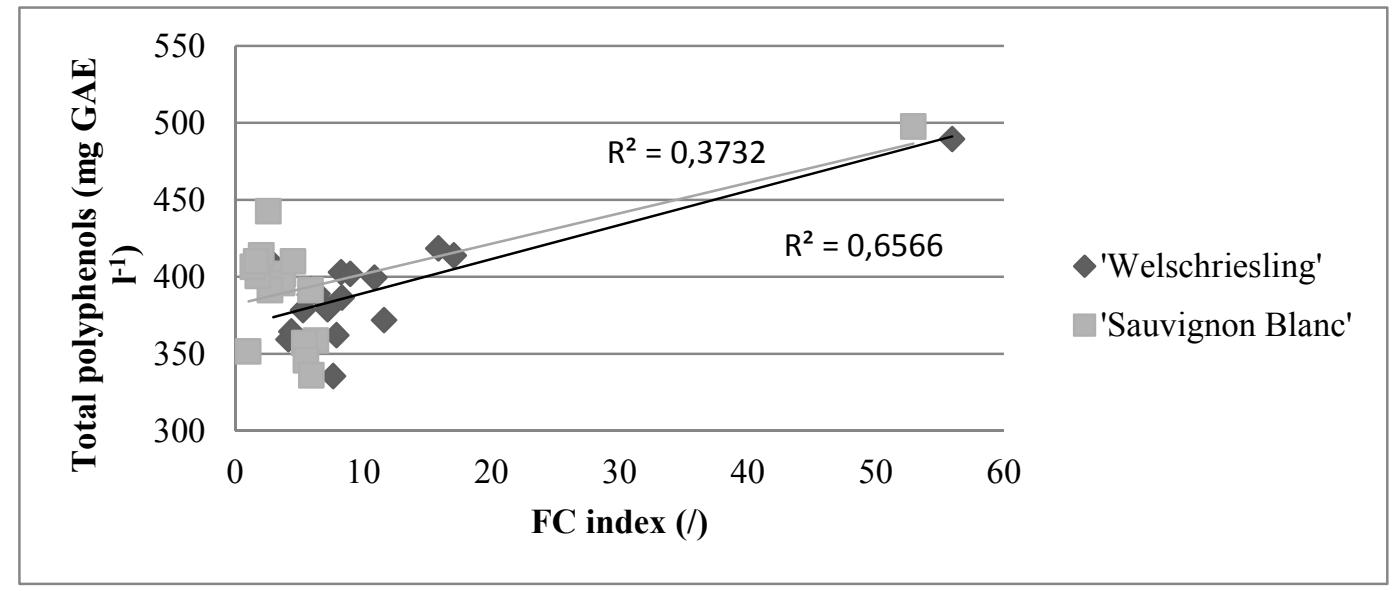

Figure 8: Correlation between $\mathrm{FC}$ index and total polyphenols content at sampling time $\mathrm{t}_{1}=0$

On the other hand Figure 9 presents that correlation between reducing sugars and FC index at sampling time $\mathrm{t}_{1}=0$ was strong $\left(\mathrm{R}^{2}=0.6879\right)$ of both welschriesling and sauvignon blanc wines. The correlation between reducing sugars and FC index was even stronger at sampling time $t_{5}=76$ days $\left(\mathrm{R}^{2}=0.8449\right)$. It means that the amount of reducing sugars influence on values of FC index.

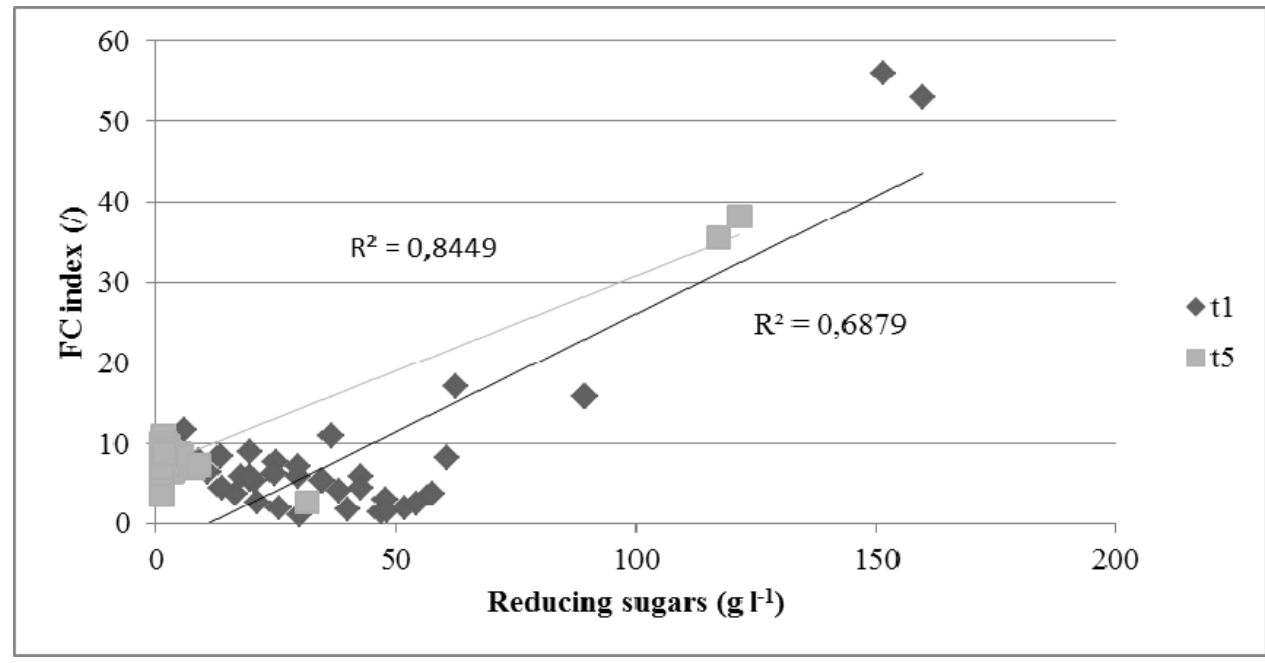

Figure 9: Correlation between reducing sugars and FC index at sampling times $t_{1}=0$ and $t_{5}=76$ days

\section{CONCLUSIONS}

Based on the obtained results, decrease of total polyphenols content and therefore decrease of antioxidant potential of wine during wine ageing on lees was observed. The total polyphenols content has decreased in average for $16.1 \%$ (in the range from 36 to $105 \mathrm{mg}$ GAE $\mathrm{l}^{-1}$ ) in welschriesling wines and for $18.7 \%$ (in the range

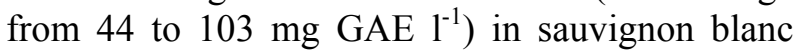
wines. Antioxidant potential of wines has decreased in average for $16.0 \%$ (in the range from
0.04 to $0.80 \mathrm{mmol} \mathrm{l}^{-1}$ ) in welschriesling wines and for $8.0 \%$ (in the range from 0.09 to $0.57 \mathrm{mmol} \mathrm{l}^{-1}$ ) in sauvignon blanc wines. We would like to emphasize that welschriesling and sauvignon blanc wines are not entirely comparable because oak chips are present in 3 samples of welschriesling wines, while oak chips were added to 7 samples of sauvignon blanc wines. 
An increase of AOP was noticed in samples with added oak chips during wine ageing. We can assume that it is because of expected additional extraction of polyphenols from oak chips into wine. For comparison, in samples with added oak chips into grape must the total polyphenols decreased in average for $15.5 \%$ in 76 days, while in the remaining samples they decreased for 18.4
$\%$. AOP of wines with added oak chips has decreased in average for $3.7 \%$, while in other samples it decreased in average for $15.5 \%$. The correlation between total polyphenols content and antioxidant potential showed a strong positive dependence of AOP on the content of total polyphenols in all the wines of both varieties.

\section{REFERENCES}

Abramovič, H. (2011). Antioksidanti in metodologija določanja antioksidativne učinkovitosti : učbenik za izbirni predmet na interdisciplinarnem doktorskem študijskem programu Bioznanosti. Ljubljana, Biotehniška fakulteta, Oddelek za živilstvo: 112

Brand-Williams, W., Cuvelier, M. E., Berset, C. (1995). Use of free radical method to evaluate antioxidant activity. Lebensmittel Wissenschaft und Technologie, 28: 25-30. Doi: 10.1016/S00236438(95)80008-5

Jakubowski, W., Bilinski, T., Bartosz, G. (1999). Oxidative stress during agin gof stationary cultures of the yeast Saccharomyces cerevisiae. Free Radical Biology \& Medicine, 28(5), 659-664. Doi: 10.1016/S0891-5849(99)00266-X

Kilmartin, P. A. (2010). Understanding and controlling non-enzymatic wine oxidation. In A.G. Reynolds (Ed.), Managing wine quality (pp. 432-458). Cambridge: Woodhead Publishing. Doi: 10.1533/9781845699987.2.432

Košmerl, T., Bertalanič, L., Maraš, V., Kodžulović, V., Šućur, S., Abramovič, H. (2013). Impact of yield on total polyphenols, anthocyanins, reducing sugars and antioxidant potential in white and red wines produced from Montenegrin autochthonous grape varieties. Food Science and Technology, 1(1), 7-15.

Košmerl, T., Cigić, B. (2008). Antioxidant potential and phenolic composition of white and red wines. Le Bulletin de l'OIV, 81, 926/928, 251-259.
Košmerl, T., Kač, M. (2010.) Kemijske analize in postopki čiščenja vina. Laboratorijske vaje pri izbirnem predmetu Vinarstvo. Ljubljana, Biotehniška fakulteta, Oddelek za živilstvo: 75.

Paixão, N., Perestrelo, R., Marques, J. C., Câmara, J. S. (2007). Relationship between antioxidant capacity and total phenolic content of red, rosé and white wines. Food Chemistry, 105: 204-214. Doi: 10.1016/j.foodchem.2007.04.017

Peréz-Serradilla, J. A., Luque de Castro, M. D. (2008). Role of lees in wine production: A review. Food Chemistry, 111, 447-456. Doi: 10.1016/j.foodchem.2008.04.019

Salmon, J. M., Fornairon-bonnefond, C., Mazauric, J. P. (2002). Interactions between wine lees and polyphenols: influence on oxygen consumption capacity during simulation of wine aging. Journal of Food Science and Technology, 67, 1604-1609. Doi: 10.1111/j.1365-2621.2002.tb08691.x

Serafini, M., Maiani, G., Ferro-Luzzi, A. (1998). Alcohol-free red wine enhances plasma antioxidant capacity in humans. Journal of Nutrition, 128, 6, 1003-1007.

Singleton, V.L., Rossi, J. A. Jr. (1965). Colorimetry of total phenolics with phosphomolybdicphosphotungstic acid reagents. American Journey of Enology and Viticulture, 16: 144-158. 